\section{Summary / learning points}

- acute pancreatitis can occur as a complication of falciparum malaria

- persistent and severe abdominal pain may be presenting manifestation of acute pancreatitis in $P$ falciparum infection

- serology of pancreatitis should be ordered routinely in falciparum malaria

- pancreatitis should be considered in the spectrum of disease associated with $P$ falciparum infection

Box 3
The list of identifiable causes of pancreatitis is growing and pancreatitis should be considered in the spectrum of disease associated with $P$ falciparum infection.

\section{Final diagnosis}

Acute pancreatitis complicating falciparum malaria.

Keywords: acute pancreatitis; malaria; Plasmodium falciparum
1 Banks PA. Acute pancreatitis. In: Haibrich WS, Schaffner F, Berk JE, eds. Bockus Gastroenterology, 5th edn. Philadephia: WB Saunders Company, 1995; pp 2888-917.

2 Case records of the Massachusetts General Hospital (case 35-1989). N Engl f Med 1989;321:597-605.

3 Sheehey TW, Reba RC. Complications of falciparum malaria and their treatment. Ann Intern Med 1967;66:8079 .

4 Gurman G, Schlaeffer F, Alkan M, Heilig I. Adult respiratory distress syndrome and pancreatitis as complications of falciparum malaria. Crit Care Med 1988;16:205-6. 5 Steinberg W, Tenner S. Acute pancreatitis. $N$ Engl f Med 1994;330:1198-1210

6 World Health Organization. Severe and complicated malaria. Trans $R$ Soc Trop Med Hyg 1990;84 (suppl 2):1-65.

7 White NJ, Breman JG. Malaria and babesiosis. In: Isselbacher $\mathrm{KJ}$, Braunwald $\mathrm{E}$, Wilson $\mathrm{JD}$, et al, eds. Harrison's Principles and practice of medicine, 13th edn. New York: McGraw Hill Inc, 1994;

8 Krogsted DJ. Plasmodium species (malaria). In: Mandell GL, Bennet JE, Dolin R, eds, Principles and practice of infectious diseases. 4th edn. New York: Churchill Livingstone, 1995; pp 2415-7.
9 Bradley D, Newbold CI, Warrell DA. Malaria. In: Weatherall DJ, Ledingham TG, Warrell DA, eds. Oxford: Oxford University Press, 1996; pp 835-63.

10 Marcial MA, Marcial-Rojas RA. Protozoal and helminthic infections. In: Kissane JM, ed. Anderson's Pathology, 9th edn. St Louis: CV Mosby Company, 1990; pp 205-6

11 Boonpucknavig V, Boonbpucknavig S. The histopathology of malaria. In: Wersdorfer WH, Mc Cregor IA, eds. The principles and practice of malariology. Edinburgh: Churchill pivingstone, 1988; pp 673-734.

12 Lichtman AR, Mohracken S, Englebrecht M, Bigalke M. Pathophysiology of severe forms of falciparum malaria. Crit Care Med 1990;16:205-6.

13 White NJ, Ho M. The pathophysiology of malaria. Adv Parasitol 1992;31:34-173.

14 Clark IA. Monokines and Iymphokines in malarial pathology. Ann Trop Med Parasitol 1987;577-85.

\title{
Metabolic acidosis
}

\author{
M Souheil Darwich, Waddah Allaf
}

\section{Department of Medicine, Wright State University, Good Samaritan Hospital and Health Center, 3535 Salem Ave, Dayton, OH 45406, USA M S Darwich}

50 Gibson Blvd, Apt\# B7, Valley Stream, NY 11581 , USA

W Allaf

Accepted 21 January 1998
A 60 -year-old woman on haemodialysis secondary to end-stage renal disease, was brought to the emergency room with recent onset of weakness, decreased consciousness and shortness of breath. She has a history of diabetes mellitus, hypertension and coronary artery disease.

Her medications on admission to the emergency room were: hydralazine, quinidine sulphate, catapress patch, lorazepam, dipyridamol, propulsid, nifidepine $\mathrm{XL}$, metformin $\mathrm{HCl}$, promethazine, and zolpidem tartrate. Physical examination revealed the following: respiratory rate 26 breaths/min and shallow, pulse 104 , blood pressure $120 / 70 \mathrm{mmHg}$, afebrile. Physical examination was otherwise remarkable for only mild abdominal tenderness. Laboratory investigation revealed: sodium $141 \mathrm{mmol} / 1, \mathrm{HCO}_{3} 9 \mathrm{mmol} / \mathrm{l}$, blood urea nitrogen $36 \mathrm{mg} / \mathrm{dl}$, creatinine $9.7 \mu \mathrm{mol} / \mathrm{l}$, glucose $172 \mathrm{mmol} / \mathrm{l}$, amylase $168 \mathrm{mmol} / \mathrm{l}$, alanine transaminase $19 \mathrm{IU} / \mathrm{l}$, serum ketones $1: 4$ dilution, lactic acid $17.4 \mathrm{mmol} / \mathrm{l}$; whole blood count was normal. Arterial blood gas: $\mathrm{pH} 6.88, \mathrm{pCO}_{2} 9.5, \mathrm{pO}_{2}$ $153, \mathrm{HCO}_{3} 1.8, \mathrm{SaO}_{2} 97.2$ on room air.

During her stay in the emergency room, the patient became more lethargic and tachypnoeic, eventually requiring intubation and mechanical ventilation.

\section{Question}

What is the most likely diagnosis: sepsis, diabetic ketoacidosis, drug-related side-effect, uraemic acidosis, or salicylate overdose? 


\section{Answer}

The patient's illness is probably a drug-related side-effect.

\section{Discussion}

The patient has severe metabolic acidosis, most probably due to metformin. Metformin is a biguanide oral hypoglycaemic agent. ${ }^{1}$ It can be used alone or in combination with sulphonylureas or insulin. The mechanism of action ${ }^{2-4}$ has been thought to be due to:

- increased glucose utilisation

- decreased glucose production

- increased glucose metabolism and lactate formation in the intestine

- reduced hepatic gluconeogenesis

- possibly reduced glucose absorption by the intestine.

Side-effects from metformin are rare, but potentially fatal. It can occasionally cause lactic acidosis. ${ }^{5}$ The half-life of metformin after oral administration is 4.0 to 8.7 hours. It is excreted by the kidneys. When creatinine clearance is decreased, the elimination of metformin is prolonged and may cause lactic acidosis. In end-stage renal disease its oral administration is contraindicated. Metformin can also cause lactic acidosis in the presence of cardiovascular, pulmonary, and hepatic disorders. It is recommended that metformin be discontinued prior to surgery, administration of contrast dyes, sepsis, and acute cardiovascular and gastrointestinal events.

In the above case, metformin was discontinued, the patient underwent haemodialysis and an intravenous bicarbonate drip was initiated. Within 24 hours she improved dramatically with the lactic acid level dropping significantly and subsequent improvement in the metabolic acidosis. Physicians trained after 1976 may not be familiar with the side-effects of metformin and other biguanides. Efforts should be made to alert more recently qualified physicians to these potential side-effects, as these medications are regaining their popularity.

\section{Final diagnosis}

Severe metabolic acidosis, most probably due to metformin.

Keywords: lactic acidosis; metformin; renal failure; adverse drug reaction
1 Baily CJ. Metformin: an update. Gen Pharmacol 1993;24:1299-309.

2 Sirtori CR, Pasik C. Re-evaluation of biguarnide, metformin: mechanism of action and. tolerability. Pharmacol Res 1994;30:187-228.

3 Fantus IG, Brosseau R. Mechanism of action of metformin: insulin receptor and postreceptor effects in vitro and vivo. $\mathcal{f}$ Clin Endocrinol Metab 1986;63:898-905. 4 Goo AK, Carson DS, Bjelajac A. Metformin, a new
treatment option for non-insulin dependent diabetes melli-
tus. $\mathcal{F}$ Fam Pract 1996;42:612-8. 5 Lim PS, Huang CC, Wei JS. Metformin induced lactic aci-
dosis. F Formos Med Assoc 1992;91:374-6. 